\title{
The Relationship Between C-Reactive Protein/Albumin Ratio and Radiological Findings in Patients with COVID-19
}

\section{COVID-19 Hastalarında C-Reaktif Protein/Albümin Oranı ile Radyolojik Bulgular Arasındaki Illişki}

\author{
(DElif Demir1, @Ramazan Giden², \Zeliha Demir Giden³ \\ 1Harran University, Faculty of Medicine, Department of Medical Biochemistry, Şanlıurfa, Turkey \\ ${ }^{2}$ Harran University, Faculty of Medicine, Department of Emergency Medicine, Şanlıurfa, Turkey \\ ${ }^{3}$ Viranşehir State Hospital, Department of Chest Diseases, Şanlıurfa, Turkey
}

\begin{abstract}
Aim: Our aim in this study is to determine the C-reactive protein/ Albumin ratio (CAR) values of computed tomography (CT) -positive COVID-19 patients and CT-negative COVID-19 patients and to investigate the relationship between C-reactive protein/Albumin ratio and radiological images of patients.

Material and Method: A-hundred COVID-19 patients over the age of 18 were included in our study. C-reactive protein (CRP), albumin levels and lung CT scan were collected. We divided the patients into two sections: CT-positive and CT-negative. We investigated the relationship between $C T$ and CAR in patients, with and without comorbidity.

Results: The measured CRP levels and CAR in the CT-positive group were significantly higher than CT-negative group (37.76 \pm 64 , $9.05 \pm 22, p=0.001,11.8 \pm 23.2,2.12 \pm 5.42, p=0.001)$. The measured albumin levels of CT-positive group were significantly lower than the CT-negative group $(4.12 \pm 0.63,4.53 \pm 0.36, p=0.001)$. When we evaluate the patients by excluding those with comorbidity; CRP levels and CAR measured in the CT-positive group were significantly higher than in the CT-negative group. (15.94 \pm 19.2 , $6.07 \pm 7.38, p=0.013,4.57 \pm 6.82,1.38 \pm 1.75, p=0.016$ ). Although the albumin values of CT-positive patients were lower than those of CTnegative patients, no statistically significance was found.

Conclusion: In general, we found that CAR levels in CT-positive patients were significantly higher than in CT-negative patients. In cases where CT is contraindicated (such as pregnancy), CAR can be used to indicate lung involvement or to follow-up patients with pulmonary involvement.
\end{abstract}

Keywords: COVID-19, C-reactive protein/albumin ratio, radiological finding
Öz

Amaç: Bu çalışmada amacımız, bilgisayarlı tomografi (BT) -pozitif COVID-19 hastalarının ve BT-negatif COVID-19 hastalarının C-reaktif protein/Albümin oranı (CAO) değerlerini tespit etmek ve COVID-19 hastalarının C-reaktif protein/Albümin oranı ile radyolojik görüntüleri arasındaki ilişkiyi araştırmaktır.

Gereç ve Yöntem: Çalışmamıza 18 yaş üstü yüz COVID-19'lu hasta dahil edildi. C-reaktif protein (CRP), albümin seviyeleri ve akciğer BT taraması toplandı. Hastaları iki bölüme ayırdık: BT-pozitif ve BT-negatif. Komorbidite dışlanmadan ve dışlanarak CAO ve BT taraması arasındaki ilişkiyi araştırdık.

Bulgular: BT pozitif grupta ölçülen CRP seviyeleri ve CAO değerleri, BT negatif gruba göre anlamlı olarakyüksekti $(37,76 \pm 64,9,05 \pm 22, p=0,001$, $11,8 \pm 23,2,2,12 \pm 5,42, p=0,001)$. Ölçülen albümin seviyeleri BT-pozitif grupta, BT negatif gruba göre anlamlı derecede düşüktü $(4,12 \pm 0,63$,

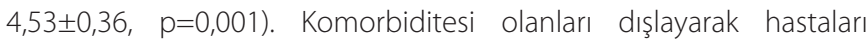
değerlendirdiğimizde; BT-pozitif grupta ölçülen CRP seviyeleri ve CAO, BT-negatif gruba göre anlamlı olarak yüksekti $(15,94 \pm 19,2,6,07 \pm 7,38$, $p=0,013,4,57 \pm 6,82,1,38 \pm 1,75, p=0,016)$. BT-pozitif hastaların albümin değerleri BT-negatif hastalarınkinden daha düşük olmasına rağmen, istatistiksel olarak anlamlı fark bulunmamıştır.

Sonuç: Genel olarak CAO düzeylerini BT-pozitif hastalarda, BT-negatif hastalara göre anlamlı olarak yüksek bulduk. Ancak komorbiditeyi dışladığımızda C-reaktif protein/albümin oranının azaldığını da göz önünde bulundurmak gerekir. BT'nin kontrendike olduğu durumlarda (gebelik gibi) olası akciğer tutulumunu işaret etmede veya akciğer tutulumu olan hastaların takiplerinde CAO kullanılabilir.

Anahtar Kelimeler: COVID-19, C-reaktif protein/albümin oranı, radyolojik bulgu 


\section{INTRODUCTION}

COVID-19 pandemic has affected the entire world in a short time. The presence of COVID-19 can present with a variety of clinical symptoms ranging from asymptomatic/mild symptoms to severe illness and death. Clinical diagnosis of COVID-19 is based on clinical signs, molecular diagnosis of the viral genome by RT-PCR, lung x-ray or CT scanning, and blood tests..$^{[1,2]}$ The most important involvement place of COVID-19 is the lung. ${ }^{[3]}$ Therefore, it is very important to show lung involvement radiologically. Although the gold standard in the disease's diagnosis is the RT-PCR test, radiological imaging has been used intensively because of the inadequacy of the test in some places and the fact that it may show false negativity in the early period. ${ }^{[4,5]}$ It should be kept in mind that radiological methods are not screening tests in the diagnosis of COVID-19, but should be used as a method to help diagnose and monitor the disease. In imaging, chest radiography, thoracic CT and thoracic ultrasonography in some limited centers are used for this purpose. Chest radiography is the first choice imaging method for demonstrating COVID-19 pneumonia. Since patients are exposed to lower doses than $C T$, they should be preferred, especially in young and pediatric age groups. However, it should be kept in mind that the limited groundglass involvement in the lungs, especially in the early phase of the disease, cannot be seen on radiography. It reported the sensitivity of chest radiography in demonstrating disease involvement to be between $30-6 \%{ }^{[6]}$ In studies, the sensitivity of the RT-PCR test in the early period of the disease was found to be $71 \%$, and thoracic CT was $98 \%{ }^{[4,5]}$ However, it should be kept in mind that thoracic CT may be normal in the early period of the disease. It recommended thorax $\mathrm{CT}$ to be used primarily in patients with symptomatic and suspicious chest radiography and in cases with suspected complications. However, what should not be forgotten is that it should evaluate the $\mathrm{CT}$ result in the light of clinical findings.

CRP is an acute phase protein released from hepatocytes after stimulation by various cytokines in response to infection, ischemia, trauma, and other inflammatory conditions. ${ }^{[7]}$ CRP levels are correlated with the level of inflammation, and its concentration level is not affected by factors such as age, sex, and physical condition. ${ }^{[8]}$ It is an important index for the diagnosis and assessment of severe pulmonary infectious diseases. ${ }^{\left[{ }^{[9]}\right.}$ High CRP levels have been found in critically ill patients in relation to prognosis and mortality. ${ }^{[10,11]}$ Albumin is the main protein in the blood and a negative acute phase reactant produced in the liver. ${ }^{[12]}$ COVID-19 have distinct hypoalbuminemia, which is likely due to hepatotoxicity of cytokine storm. ${ }^{[13]}$ It is known that low serum albumin is associated with poor prognosis and mortality. ${ }^{[13-15]}$

The CRP/Albumin ratio, which is the result of the ratio of these two parameters to each other, is the parameter that has just started to be used. The CRP/ALB ratio was first reported to identify patients with serious illness on an acute medical ward. ${ }^{[16]}$ The CRP/Albumin ratio is believed to be a more reliable predictor of inflammatory status than CRP or albumin alone. ${ }^{[17]}$ In this study, we examined the CRP/ Albumin ratios of CT-positive COVID-19 patients and CTnegative COVID-19 patients with and without comorbidity.

\section{MATERIAL AND METHOD}

We performed this study with respect to the recommendations put forward via the Declaration of Helsinki. Harran University Ethics Committees approved the study protocol (Reference No HRU/20.20.26). We carried it out in Şanlıurfa Research and Training Hospital. We performed a retrospective study. One hundred COVID-19 patients regardless of additional diseases over the age of 18 who applied to hospital were included in our study. These data include the laboratory and radiological findings of patients at the time of first admission to the hospital. CRP, albumin levels, other data and lung CT scan were collected in this study. We divided the patients into two sections: CT-positive group and CT-negative group. We investigated the relationship between CT and CAR in patients with COVID-19 patient, first without comorbidity and then with comorbidity (such as diabetes, hypertension, COPD, asthma, heart failure, and cancer).

\section{Statistical analysis}

We completed statistical analysis using IBM SPSS 25.0 (SPSS for Windows, SPSS Inc., Chicago, IL, USA). KolmogorovSmirnov test was used for normality testing of CRP, albümin and CRP/Albumin ratios. The groups were not displayed normal distribution. Mann-Whitney $U$ Test, among nonparametric tests, was used to investigate whether there were considerable differences between the groups. $\mathrm{P}<0.05$ was accepted as statistically significant.

\section{RESULTS}

Out of A-hundred patients with positive RT-PCR test, thirtynine patients were $C T$-negative and sixty-one patients were CT-positive. The gender distribution and average age of the CT-negative group and the CT-positive group included in our study are shown in Table 1. Thirty-two patients had additional diseases that would alter the level of parameters such as diabetes, hypertension, COPD, asthma, heart failure, and cancer. When we without comorbidity, thirtyfive of sixty-eight patients with COVID-19 were CT-positive and thirty-three of them were CT-negative.

\begin{tabular}{|c|c|c|}
\hline Groups & Gender (Male/Female) & Age (years) \\
\hline CT Negatif & $19 / 20$ & $38.90 \pm 14.09$ \\
\hline CT Pozitive & $28 / 33$ & $41.70 \pm 15.76$ \\
\hline
\end{tabular}


The CRP, albumin levels and CAR measured in the CT-positive patient group and the CT negative patient group included in our study are shown in Table 2. Our results without excluding comorbidity: The measured CRP levels in the CT-positive patient group were significantly higher than CT-negative patient group (37.76 $\pm 64,9.05 \pm 22, p=0.001)$. The measured albumin levels CT-positive patient group were significantly lower than CT-negative patient group $(4.12 \pm 0.63,4.53 \pm 0.36, p=0.001)$. The measured CAR in the CT-positive patient group were significantly higher than CT-negative patient group (11.8 \pm 23.2 , $2.12 \pm 5.42, p=0.001)$. CT scans of patients with COVID-19 with high CAR levels showed common lung involvement. We show the CT scans of some of our patients with high CAR in Figure 1.

\begin{tabular}{|c|c|c|c|c|c|c|}
\hline Groups & $\begin{array}{c}\text { CRP } \\
(\mathrm{mg} / \mathrm{L})\end{array}$ & $\begin{array}{c}\mathbf{P} \\
\text { value }\end{array}$ & $\begin{array}{c}\text { Albumin } \\
\text { (g/dL) }\end{array}$ & $\begin{array}{c}P \\
\text { value }\end{array}$ & $\begin{array}{c}\text { CRP/Albumin } \\
\text { Ratio }\end{array}$ & $\begin{array}{c}P \\
\text { value }\end{array}$ \\
\hline $\begin{array}{l}\text { CT Negatif } \\
\text { (39) }\end{array}$ & $9.05 \pm 22$ & & $4.53 \pm 0.36$ & & $2.12 \pm 5.42$ & \\
\hline $\begin{array}{l}\text { CT Pozitive } \\
\text { (61) }\end{array}$ & $37.76 \pm 64$ & 0.001 & & 0.001 & & 0.001 \\
\hline
\end{tabular}

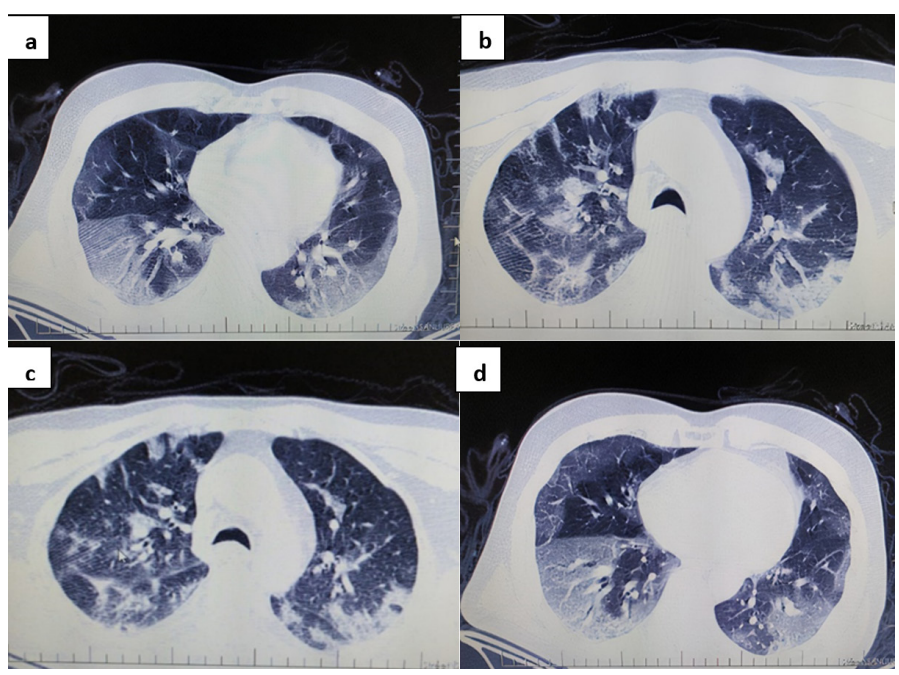

Figure 1. CT positive scans of COViD-19 positive patients (C-reactive protein/ Albumin ratio levels respectively a: 24,56 , b: 26,00, c: 18,98 , d: 16,96. a: A 44-yearold patient who presented with the complaints of cough, shortness of breath and weakness had peripherally located ground glass areas in both lung lobes. b: A 58-year-old patient who presented with the complaints of shortness of breath, fever and cough had ground glass densities scattered in both lungs upper lobes. c: A 39-year-old patient who presented with the complaints of cough, shortness of breath, and loss of taste and smell had ground glass densities scattered in the upper and lower lobes of both lungs. d: A 50-year-old patient who presented with the complaints of shortness of breath, weakness and malaise had diffuse ground glass densities in both lungs).

The results we got by excluding the comorbidities are shown in Table 3. When we evaluate patients without comorbidity the measured CRP levels and CAR in the CT-positive group were significantly higher than CT-negative group (15.94 \pm 19.2 , $6.07 \pm 7.38, p=0.013,4.57 \pm 6.82,1.38 \pm 1.75, p=0.016)$. Although the albumin values of CT-positive patients were lower than those of CT-negative patients $(4.25 \pm 0.58,4.55 \pm 0.35$, p:0.057), we found no statistically significant significance.
Table 3. Statistical comparison of C Reactive Protein (CRP), Albumin and CRP/Albumin levels of patients without comorbidities with CT positive and CT negative COVID-19

\begin{tabular}{|c|c|c|c|c|c|c|}
\hline Groups & CRP (mg/L) & $\begin{array}{c}P \\
\text { value }\end{array}$ & $\begin{array}{c}\text { Albumin } \\
\text { (g/dL) }\end{array}$ & $\begin{array}{c}P \\
\text { value }\end{array}$ & $\begin{array}{l}\text { CRP/Albumin } \\
\text { Ratio }\end{array}$ & $\begin{array}{c}P \\
\text { value }\end{array}$ \\
\hline $\begin{array}{l}\text { CT } \\
\text { Negatif } \\
\text { (33) }\end{array}$ & $6.07 \pm 7.38$ & & $4.55 \pm 0.35$ & & $1.38 \pm 1.75$ & \\
\hline $\begin{array}{l}\text { CT } \\
\text { Pozitive } \\
\text { (35) }\end{array}$ & $15.94 \pm 19.2$ & 0.013 & $4.25 \pm 0.58$ & 0.057 & $4.57 \pm 6.82$ & 0.016 \\
\hline
\end{tabular}

\section{DISCUSSION}

COVID-19 infection is a global pandemic, which has caused many deaths worldwide. Inflammation is the cellular immune response that occurs to remove damaged tissues caused by bacterial or viral infections and the causative agent from the environment. Some viruses infect lymphocytes and increase their destruction, causing lymphopenia and a decrease in serum albumin, which is a negative acute phase reactant, while increasing the levels of CRP and ferritin, which are positive acute-phase reactants. ${ }^{[18,19]}$ CRP is a type of protein produced by the liver that rises in response to inflammation. CRP levels have been associated with a variety of conditions, including severe sepsis, heart failure, and other inflammatory disease. ${ }^{[10]}$ In a study by Wang et al. ${ }^{[20]}$ many COVID-19 patients showed high CRP levels, which is consistent with other studies. The aggravated cases in this study showed significantly higher CRP levels than non-serious patients. This result suggested that CRP may be a serum marker of disease severity in 22 patients with COVID-19. Liu et al.'. ${ }^{[21]}$ study suggested that serum levels of IL- 6 and CRP have a significant correlation with the severity of COVID-19 and that these parameters can independent factors to predict disease risk. Several studies have reported data on Hypoalbuminemia in COVID-19 patients. ${ }^{[22-24]}$ Low serum albumin reflects poor nutritional status, liver and kidney dysfunction, and has been an independent predictor of poor survival in critically ill patients. ${ }^{[25]}$

In previous studies, the effectiveness of CAR as a prognosis and mortality marker, especially in malignant diseases, has been studied. ${ }^{[10,15,17]}$ CAR is an effective parameter not only as a mortality marker but also in the selection of patients to be treated aggressively. In previous studies conducted with inflammatory bowel diseases, they have shown that CAR is a useful marker for determining disease activity and who should be given early steroid treatment. ${ }^{[7,20]}$ The CAR a prognostic score to evaluate outcomes in patients with cancer, inflammation, and sepsis. ${ }^{[26]} \mathrm{Kim}$ et al. ${ }^{[27]}$ reported that the CAR at admission positively correlated with prognosis in patients with severe sepsis or septic shock treated with early targeted therapy. In a study, they have shown CAR as a predictor of mortality in patients with acute pancreatitis. It has been emphasized that CAR is a comprehensive and effective form of CRP and albumin rather than a simple ratio of CRP to albumin. ${ }^{[28]}$ 


\section{CONCLUSION}

In our study, we found that CRP levels and CAR values were significantly higher in CT-positive patients compared to CT-negative patients, and albumin levels were significantly lower in CT-positive patients. Although CRP levels and CAR values decreased numerically when we excluded patients with comorbidity, it was statistically significant. In conclusion, where $\mathrm{CT}$ is contraindicated (such as pregnancy), CAR can be used to indicate lung involvement or to follow-up patients with pulmonary involvement. We have not found any publications in the literature comparing the ratio of lung CT and CAR in COVID-19 patients (with or without comorbidity). Therefore, it should be supported by similar studies to strengthen this view.

\section{ETHICAL DECLARATIONS}

Ethics Committee Approval: This study was approved by the Harran University Ethics Committees. Sanliurfa Research and Training Hospital (Reference No. HRU/20.20.26).

Informed Consent: Because the study was designed retrospectively, no written informed consent form was obtained from patients.

Referee Evaluation Process: Externally peer-reviewed.

Conflict of Interest Statement: The author(s) declared no potential conflicts of interest with respect to the research, authorship, and/or publication of this article.

Financial Disclosure: The authors declared that this study has received no financial support.

Author Contributions: All of the authors declare that they have all participated in the design, execution, and analysis of the paper, and that they have approved the final version.

\section{REFERENCES}

1. Paranjpe I, Russak A, De Freitas JK et al. Clinical Characteristics of Hospitalized COVID-19 Patients in New York City. medRxiv. 2020.

2. Zhu J, Zhong Z, Ji P et al. Clinicopathological characteristics of 8697 patients with COVID-19 in China: a meta-analysis. Fam Med Commun Health. 2020;8(2):e000406

3. World Health Organization. Director-General's remarks at the media briefing on 2019- nCoV on 11 February 2020. https://www.who.int/ $\mathrm{dg} / \mathrm{speeches/detail/who-director-general-s-remarks-at-the-media-}$ briefingon-2019-ncov-on-11-february-2020 (Accessed on February 12, 2020).

4. T.C Sağlık Bakanlığı Halk Sağlığı Genel Müdürlüğü COVID-19 (SARS-CoV-2 Enfeksiyonu) Rehberi. Bilim Kurulu Çalışması. 12 Nisan 2020. https:// covid19bilgi.saglik.gov.tr/depo/rehberler/COVID-19_Rehberi.pdf.

5. Dashraath P, Jing Lin Jeslyn W, Mei Xian Karen L, et al. Coronavirus Disease 2019 (COVID-19) Pandemic and Pregnancy. Am J Obstet Gynecol. 2020: S0002-9378(20)30343-4.

6. Tang A, Tong ZD, Wang HL, et al. Detection of Novel Coronavirus by RTPCR in Stool Specimen from Asymptomatic Child, China. Emerg Infect Dis 2020; 26.

7. Thijs LG, Hack CE. Time course of cytokine levels in sepsis. Intensiv. Care Med. 1995;21:258-63.

8. Bilgir O, Bilgir F, Calan M. Comparison of pre-and post-levothyroxine high-sensitivity C-reactive protein and fetuin-A levels in subclinical hypothyroidism.Clinics 2015;70(2):97-101.
9. Chalmers S, Khawaja A, Wieruszewski PM, Gajic O, Odeyemi Y. Diagnosisand treatment of acute pulmonary inflammation in critically ill patients: therole of inflammatory biomarkers. World J Crit Care Med 2019;8(5):59-71.

10. Ho KM, Lee KY, Dobb GJ, Webb SA. C-reactive protein concentration as a predictor of in-hospital mortality after ICU discharge: A prospective cohort study. Intensiv. Care Med. 2008;34:481-7.

11. Ho KM, Dobb GJ, Lee KY, Towler SC, Webb SA. C-reactive protein concentration as a predictor of intensive care unit readmission: $A$ nested case-control study. J. Crit. Care. 2006;21:259-65.

12. Kaplan M, Ateş I, Akdoğan Kayhan M, Kaçar S, Akpınar M. C-Reaktif Protein/Albümin Oranının Sirotik Hastalarda Prognostik Amaçlı Kullanımı Akademik Gastroenteroloji Dergisi. 2018;110-6.

13. Huang W, Li C, Wang Z, et al. Decreased serum albumin level indicates poor prognosis of COVID-19 patients: hepatic injury analysis from 2,623 hospitalized cases. Sci. China Life Sci. 2020;1-9.

14. Artero A, Zaragoza R, Camarena JJ, Sancho S, Gonzalez R, Nogueira JM. Prognostic factors of mortality in patients with community-acquired bloodstream infection with severe sepsis and septic shock. J. Crit. Care. 2010;25:276-81.

15. Goldwasser P, Feldman J. Association of serum albumin and mortality risk. J. Clin. Epidemiol. 1997;50:693-703.

16. Fairclough E, Cairns E, Hamilton J, et al. Evaluation of a modified early warning system for acute medical admissions and comparison with C-reactive protein/albumin ratio as a predictor of patient outcome. Clin Med, 2009;9:30-3.

17. Haruki K, Shiba H, Shirai Y, et al. The C-reactive Protein to Albumin Ratio Predicts Long-Term Outcomes in Patients with Pancreatic Cancer After Pancreatic Resection. World J Surg. 2016;40(9):2254-60.

18. Hong KW, Cheong HJ, Choi WS, et al. Clinical courses and outcomes of hospitalized adult patients with seasonal influenza in Korea, 2011-2012: Hospital-based Influenza Morbidity \& Mortality (HIMM) surveillance. J Infect Chemother 2014; 20(1): 9-14.

19. Giacomelli A, Pezzati L, Conti F, et al. Self-reported Olfactory and Taste Disorders in Patients With Severe Acute Respiratory Coronavirus 2 Infection: A Cross-sectional Study. Clin Infect Dis 2020; 71(15): 889-90.

20. Wang G, Wu C, Zhang Q, et al. C-reactive protein level may predict the risk of COVID-19 aggravation. Open Forum Infect Dis. 2020;7(5): ofaa153.

21. Liu F, Li L, Xu M, et al. Prognostic value of interleukin-6, C-reactive protein, and procalcitonin in patients with COVID-19. J Clin Virol. 2020;127:104370.

22. Chen T, Wu D, Chen $H$, et al. Clinical characteristics of 113 deceased patients with coronavirus disease 2019: retrospective study. BMJ. 2020;368: m1091.

23. Liu Y, Yang Y, Zhang C, et al. Clinical and biochemical indexes from 2019$\mathrm{nCoV}$ infected patients linked to viral loads and lung injury. Sci China Life Sci. 2020;63:364-74

24. Chen G, Wu D, Guo W, et al. Clinical and immunological features of severe and moderate coronavirus disease 2019. J Clin Invest. 2020;130:2620-9.

25. Ko JH, Park GE, Lee JY et al. Predictive factors for pneumonia development and progression to respiratory failure in MERS-CoV infected patients. J Infection 2016;73:468-75.

26. Karayiannis D, Bouloubasi Z, Baschali A, et al. Postoperative C-reactive protein to albumin ratio as a diagnostic tool for predicting complications after abdominal surgery. Clin Nutrition ESPEN 2018;24:176.

27. Kim MH, Ahn JY, Song JE, et al. The C-reactive protein/albumin ratio as an independent predictor of mortality in patients with severe sepsis or septic shock treated with early goal-directed therapy. PLoS One 2015;10:e0132109.

28. Kaplan M, Ates I, Akpinar MY, et al. Predictive value of C-reactive protein/ albumin ratio in acute pancreatitis. Hepatobiliary Pancreat Dis Int 2017; 16:424-30. 